\title{
Ethnopharmacognostic survey on botanical compendia for potential cosmeceutic species from Atlantic Forest
}

\author{
Maique W. Biavatti ${ }^{1 *}$, Vanessa Marensi ${ }^{1}$, Silvana N. Leite' ${ }^{2}$ Ademir Reis $^{3}$

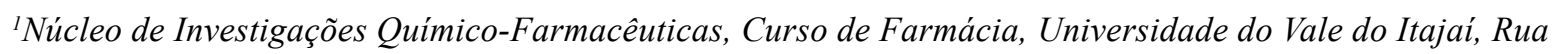 \\ Uruguai 458, 88302-202, Itajaí, Santa, SC, Brazil, \\ ${ }^{2}$ Curso de Farmácia, Programa de Mestrado em Saúde e Gestão do Trabalho, Universidade do Vale do Itajaí, \\ Rua Uruguai 458, 88302-202, Itajaí, Santa, SC, Brazil, \\ ${ }^{3}$ Departamento de Botânica, Universidade Federal de Santa Catarina, Caixa-Postal 476, \\ 88040-900, Florianópolis, SC, Brazil
}

\begin{abstract}
RESUMO: "Levantamento etnofarmacognóstico em compêndios botânicos de espécies da Mata Atlântica com potencial cosmecêutico". A Mata Atlântica é um dos ecossistemas mais ameaçados do planeta, sendo reconhecida como uma área de grande biodiversidade sob alto nível de stress. A área cosmecêutica abrange medicamentos de uso tópico e cosméticos, e o uso de produtos naturais para aplicação externa sempre foi observado em diversas culturas. Este trabalho trata de uma análise etnofarmacognóstica de dois compêndios botânicos $(\mathrm{CB})$ : Dicionário das Plantas Úteis do Brasil - e das exóticas cultivadas, compilado por Pio Correa (PC) e Flora Ilustrada Catarinense (FIC). Destes compêndios, foram selecionadas espécies com uso cosmecêutico ou com características fisico-químicas e organolépticas relacionadas. Essas espécies selecionadas foram analisadas quanto à validade da nomenclatura botânica e a ocorrência de publicação científica, e quanto ao risco de extinção. PC e FIC apontaram que 245 espécies vegetais, pertencendo a 98 famílias, possuem uso cosmecêutico no Brasil. As famílias mais citadas foram: Asteraceae, Fabaceae, Myrtaceae, Annonaceae, Clusiaceae, Anacardiaceae, Apiaceae, Bignoniaceae e Solanaceae. As partes usadas mais citadas foram cascas, folhas e partes aéreas. As propriedades mais citadas foram efeito tônico e adstringente, seguido de efeito cicatrizante, emoliente, antiinflamatório, antiúlcera, anti-séptico, parasiticida e clareador da pele. De acordo com a pesquisa bibliográfica no Pubmed, a maioria das espécies selecionadas (65\%) não foi investigada farmacológica e quimicamente.
\end{abstract}

Unitermos: Mata Atlântica, cosmecêuticos, etnobotânica.

\begin{abstract}
The Atlantic Forest is one of the most endangered ecosystems on earth, and is acknowledged as an area with truly exceptional levels of biodiversity under enormous levels of stress. Cosmeceutics cover a border area between pharmaceuticals for skin diseases and cosmetics. Natural products for external application, to improve the appearance of the skin or for skin treatment, have always been observed and used by native cultures. The present work deals with the ethnopharmacognostic analysis of two botanical compendia (BC), named: Dicionário das Plantas Úteis do Brasil - e das exóticas cultivadas, compiled by Pio Correa (PC) Flora Ilustrada Catarinense (FIC). From these BC, reported species with cosmeceutical uses or with related physico-chemical or organoleptic characteristics were selected, updated, searched for scientific background and highlighted if endangered. PC and FIC specified that 245 plant species, belonging to 98 plant families, are used in Brazil for cosmeceutical, cosmetic or skin remedies. The families most widely represented were Asteraceae, Fabaceae, Myrtaceae, Annonaceae, Clusiaceae, Anacardiaceae, Apiaceae, Bignoniaceae and Solanaceae The most frequently cited plant parts were bark, followed by leaves and aerial parts. The most frequently cited properties were astringency and tonic effect followed by uses in skin disorders and wound healing, emollient characteristic, anti-inflammatory uses and healing of skin ulcers, antiseptic effects, parasiticide and skin lightening properties and aphrodisiacs. According to the Pubmed survey, most of the selected species $(65 \%)$ have not been previously investigated for potential cosmeceutical applications, nor have their chemical composition been investigated.
\end{abstract}

Keywords: Atlantic forest, cosmeceutics, ethnobotany. 


\section{INTRODUCTION}

\section{Overview}

Biodiversity supplies the structure of the ecosystems that support essential living resources, including wildlife, fisheries and forests, helping to provide basic human needs such as food, and medicines. It comprises the ecosystems that maintain oxygen in the air, enrich the soil, purify the water, and regulate the climate, besides its recreational, cultural, spiritual and aesthetic values. The increasing consumption of resources, and the growing populations in society have led to a rapid loss of biodiversity, eroding the capacity of the earth's natural systems to provide the essential goods and services on which human communities depend (Arcanjo, 2000).

The Atlantic Forest is one of the most endangered ecosystems on earth, and is acknowledged as an area with truly exceptional levels of biodiversity, but it is also an area which is under enormous levels of stress, containing a high level of endemism. The Atlantic Forest is home to about $70 \%$ of all Brazilians and contains some of the largest urban centres on the continent. The South Brazilian State of Santa Catarina was originally totally covered by Atlantic Forest; today less than $8 \%$ of the original forest remains, occurring mostly in isolated remnants scattered throughout a landscape dominated by agricultural and extractive practices. At a provincial level, people are slowly becoming aware of the importance of the forest and the need to conserve it, but there is still a widespread misconception that the forest is unproductive. Different States still have contradictory policies and there lacks a common strategy for forest conservation (Galindo-Leal; Camara, 2003). It is therefore advisable that conservation mechanisms such as sustainable exploitation be planned to stimulate the continuity of efforts, lessening dependence on international funding. The Convention on Biological Diversity (CBD), signed in 1992, has been ratified by 178 countries, including Brazil, and provides a legal framework for a comprehensive ecosystembased approach to conservation. It introduced the term access and its respective legal implications in three different contexts: access to genetic resources, access to technology, and access to the benefits derived from the use of biodiversity. In accordance with this treaty, and the tasks required for its implementation, the Brazilian Congress and Government have been working since 1995 to formulate the domestic legislation required to regulate the $\mathrm{CBD}$ vector which deals with access to genetic resources.

The last piece of legislation already in force is Provisional Decree 2052 (published for the first time in June 2000). This is the current Brazilian regulation on access to genetic resources, which disciplines substantial parts of the Convention of Biological Diversity. It recognizes the rights of indigenous peoples and local communities over their knowledge; defines their participation in agreements for use of the knowledge; and establishes general legalization on all uses prior to the day of the decree and the possibility of a registry to entitle the rights (Sant'Ana, 2002).

\section{Cosmeceuticals}

As in the case of functional foods "food that claims to have health benefits beyond basic nutrition" (Noonan; Noonan, 2004), cosmeceutics cover a border area between pharmaceuticals for skin diseases and cosmetics (that have been labelled as substances for skin application without therapeutic benefits). Natural products for external application, to improve the appearance of the skin or for skin treatment, have always been observed and used by native cultures, but have been neglected in recent ethnobiological and ethnopharmaceutical studies (Pieroni et al., 2004).

There is increasing interest worldwide, in the use of natural ingredients in foods and cosmetics (Leung; Foster, 2003). As an example, the root extract of Pothomorphe umbellata (Pariparoba, the indigenous name for a common shrub found in the Atlantic Forest) is being patented for pharmaceutical and dermocosmetics purposes, for the prevention and treatment of cell damage caused by exposure to UV rays and ageing. It contains 4-nerolidylcathecol, an antioxidant compound which protects the cell membrane. Pariparoba is used, over the long term, for digestive problems, liver disease and burns (Moraes, 1986; Ropke et al., 2002, 2003).

Few recent ethnobotanical field studies have been carried out in the Atlantic Forest, and those that do exist have mainly investigated medicinal plants (Di Stasi et al., 2002, Mendonça-Filho; Menezes, 2003; Souza et al., 2004; Morais et al., 2005; Brandão et al., 2006; Agra et al., 2007). Although, primary contact with traditional medical practitioners is the ideal method for carrying out ethnobotanical analysis, there are cases where traditional healers are no longer available. As a surrogate, Botanical Compendia (BC) - which are based on direct work with primary information - may provide sufficient insight to identify potential new lead species. To date, however, there has been no established protocol for investigating BC. Buenz et al. (2004) have developed a technique for carrying out ethnobotanical analysis on historic texts, using Ambonese Herbal: Volume I as a case example (Buenz et al., 2005).

The present work deals with the ethnopharmacognostic analysis of two botanical compendia (BC), named: Dicionário das Plantas Úteis do Brasil - e das exóticas cultivadas, compiled by Pio Correa (PC) (1926) in which species are alphabetically classified by popular name, without description of origin, but occurring in Brazilian territory, and Flora Ilustrada Catarinense (FIC). It is composed of 60 
fascicules of botanical families presenting genera and species collected in the State of Santa Catarina - Brazil, and does not discriminate between cultivated and natural species.

From these BC, species were selected which have reported cosmeceutical uses or physico-chemical or organoleptic characteristics which have possible cosmeceutical applications, were chosen. Some of the species may be promising sources of new natural ingredients for cosmetic purposes, and also of new pharmacologically active compounds. Expected outputs with this work are an improvement in the valorization of native resources, and the promotion of sustainable use of species in the Atlantic rainforest.

\section{MATERIAL AND METHODS}

\section{Selection of botanical compendia}

Dicionário das Plantas Úteis do Brasil - e das exóticas cultivadas: Compiled by Pio Correa (PC). Manoel Pio Corrêa (1874-1934) was a naturalist from the Botanical Garden of Rio de Janeiro, and a member of the Société Botanique de France. The first volume of his Dictionary was published on 1926, and the subsequent volumes were published in 1931, 1952, 1969, 1974 and 1975, being re-edited by the Instituto Brasileiro de Desenvolvimento Federal - IBDF in 1984, in conjunction with the Ministry of Agriculture (1984). His opera has always been a classical reference for research on Brazilian flora, as a starting point.

Corrêa MP 1984. Dicionário de Plantas Úteis do Brasil, Ministério da Agricultura, Instituto Brasileiro de Desenvolvimento Florestal, Brasília, DF, vol. I 747 pp.; vol. II 777 pp.; vol. IV 765 pp.; vol. V 687 pp.

Flora Ilustrada Catarinense (FIC): Raulino Reitz (1919-1990) dedicated his life to surveying the flora of Santa Catarina. He discovered five genera and 327 new species of plants, and founded the Herbarium Barbosa Rodrigues which today has around 70,000 exsiccates. He conceived and edited the Flora Ilustrada Catarinense with 150 families in 172 fascicules. Sixty botanical specialists have collaborated in the elaboration of monographs, each in his or her own area of specialty. Each plant family is compiled in one fascicule, in the form of an encyclopaedia. To access the complete list of publications see: http://www.cttmar.univali.br/ hbr/ fic.htm

\section{Experimental design}

After the selection of PC and FIC, all citations referring to external applications (topical treatments) of native species of Atlantic forest were extracted and tabled (Table 1). Potential pharmacological functions of plants for the skin, extrapolated from their uses in the treatment of certain disorders, were considered.
Initially, the selected species with cited applications in a) skin and annexes pathologies (such as dermatitis, dermatosis, photo protection, microbial and viral infections, among others), b) prevention of ageing and skin maintenance (with antioxidant, astringent, tonic, hydrating and emollient activities, among others) and c) with physico-chemical or organoleptic characteristics (aromatic, foaming properties, colorant, etc) with possible cosmeceutical applications, were referenced through the International Plant Names Index (The Plant Names Project, 1999) and $\mathrm{W}^{3}$ TROPICOS (Missouri Botanical Garden, 2003), to identify binomial names and rule out synonymy or misspelling. The botanical names and author citations were also verified through these two databases. All plant species described as useful were investigated in the PUBMED database, seeking scientific information related to the profile of a cosmeceutical application (biological assays and isolated compounds). All the data collected were consolidated into a table; plants that were recognized for specific uses in PC and FIC but which did not have entries in PUBMED were cited as plants that might warrant further investigation.

\section{RESULTS AND DISCUSSION}

PC and FIC specified that 245 plant species, belonging to 98 plant families, are used in Brazil for cosmeceutical, cosmetic or skin remedies. Table 1 outlines all the plants detailed by the two compendia and the results of the scientific name search in the Pubmed database. The expanded data summarized in the Table 1 can be accessed in Marensi (2004). The families most widely represented were Asteraceae (13 species from Baccharis, Blanchetia, Calea, Elephantopus, Helenium, Heterothalamus, Leucopsis, Melampodium, Vernonia), Fabaceae (11 species from Acacia, Bauhinia, Cassia, Enterolobium, Erythrina, Myrocarpus, Parapiptadenia, Pithecolobium, Pterodon), Myrtaceae (11 species from Calyptranthes, Eugenia, Myrcia, Psidium, Stenocalyx, Pseudocaryophyllus), Annonaceae (8 species from Annona, Guatteria, Rollinia, Xylopia), Clusiaceae (7 species from Hypericum and Kielmeyera), Meliaceae and Anacardiaceae also with 7 species; Apiaceae, Bignoniaceae and Solanaceae (6 species each). The most frequently cited plant parts were bark $(n=52)$ or bark and other parts of the plant $(n=17)$, followed by leaves $(\mathrm{n}=56)$ and aerial parts $(\mathrm{n}=33)$. Roots, flowers, seeds, stems, fruits, rhizomes, resins, pulp and ashes were also reported.

The most frequently cited properties were astringency $(n=68)$ and tonic effect $(n=33)$, followed by uses in skin disorders $(\mathrm{n}=25)$ and wound healing $(\mathrm{n}=$ $22)$, emollient characteristic $(n=22)$, anti-inflammatory uses $(n=14)$ and healing of skin ulcers $(n=12)$, antiseptic effects $(n=05)$, parasiticide and skin lightening properties ( 2 each) and aphrodisiacs $(n=8)$. The sum of listed references to physico-chemical and organoleptic 


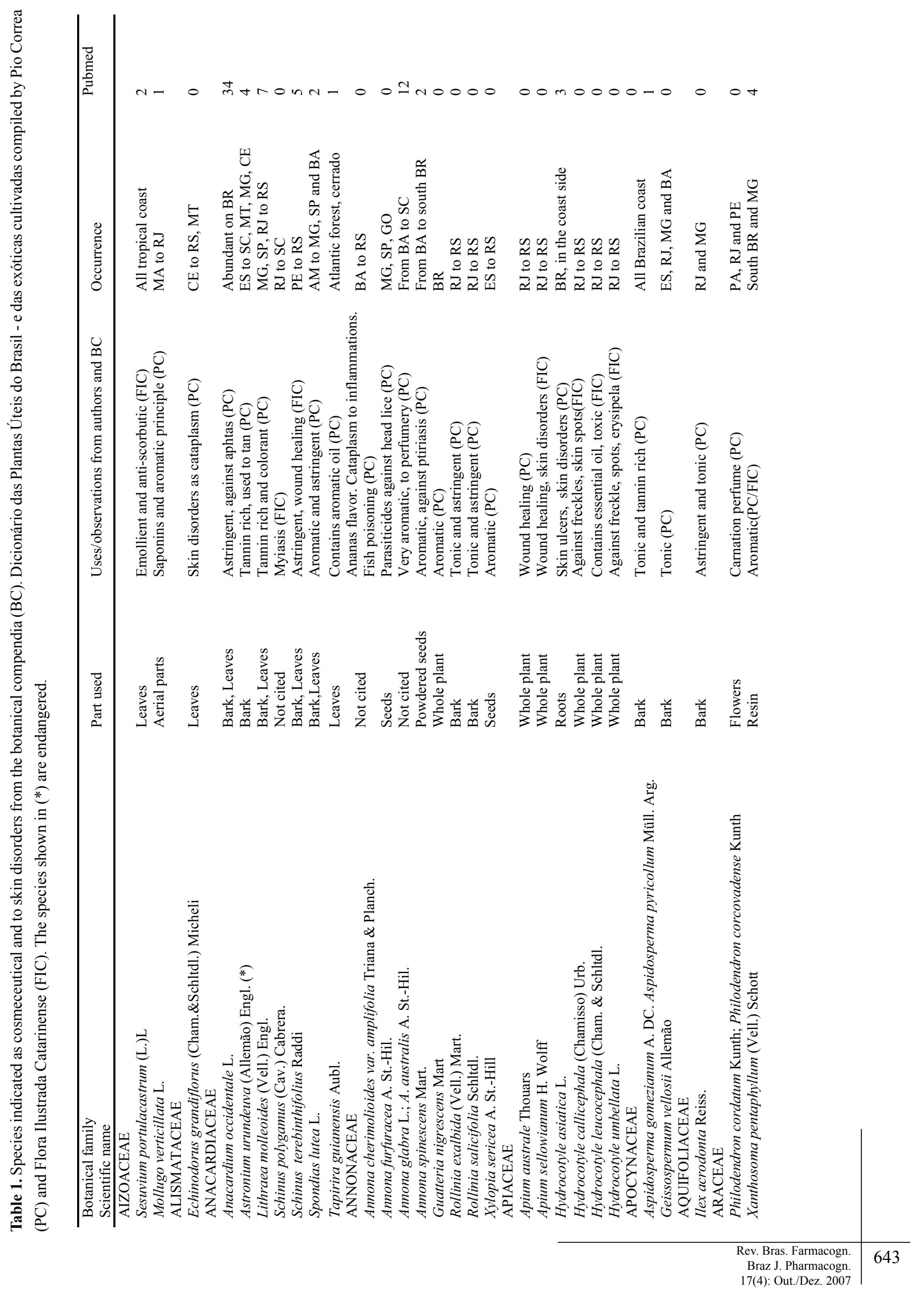




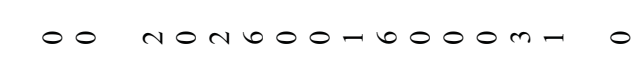

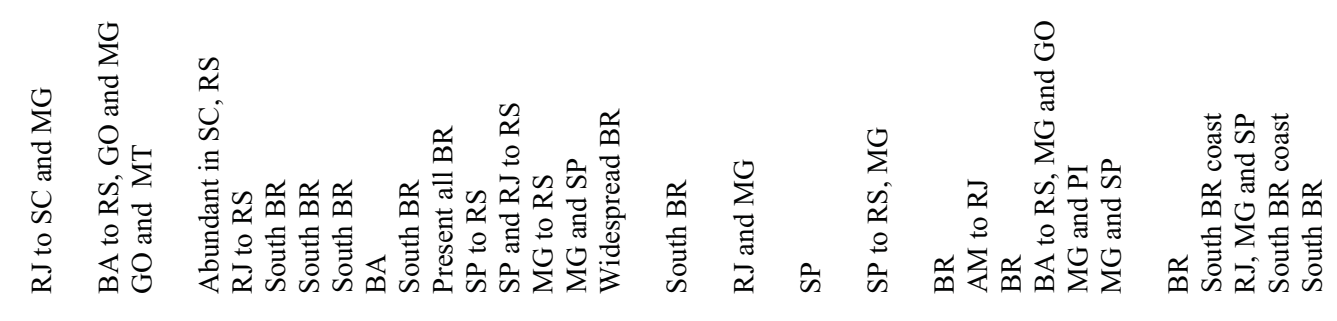

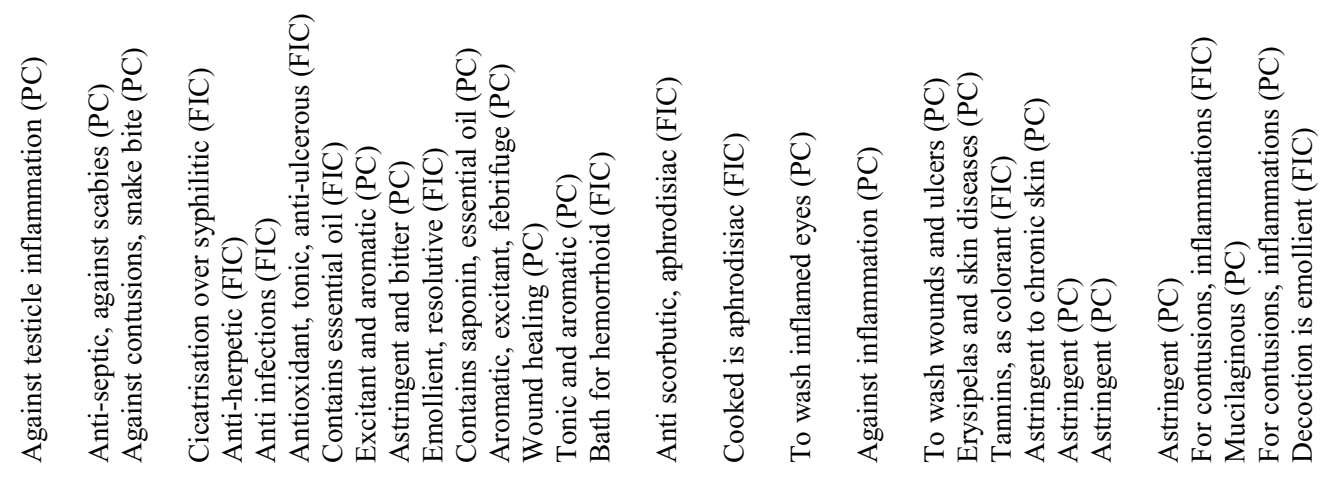

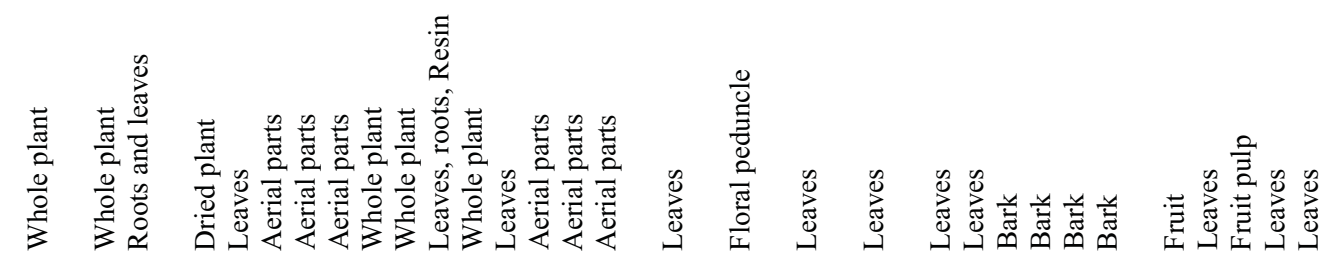

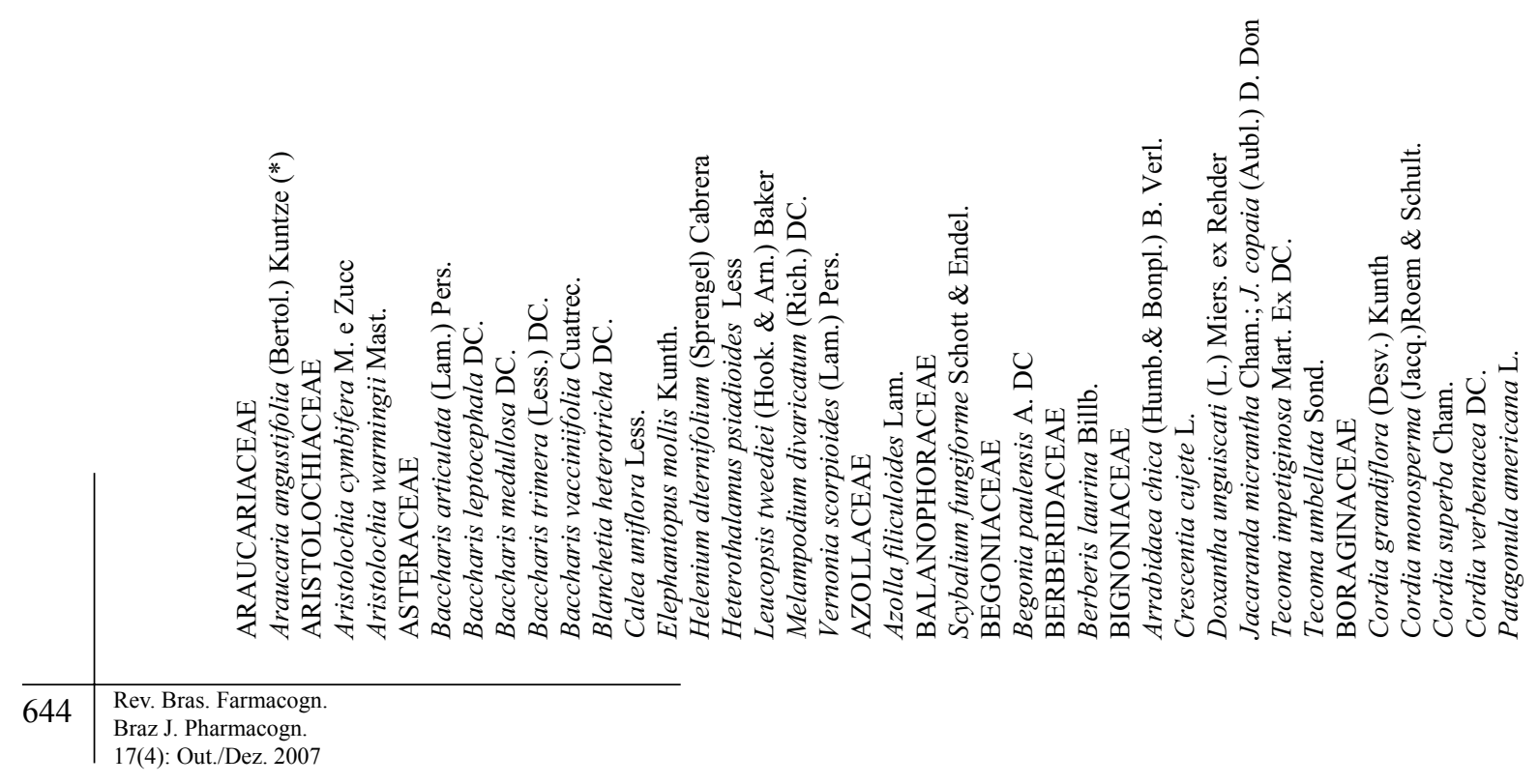




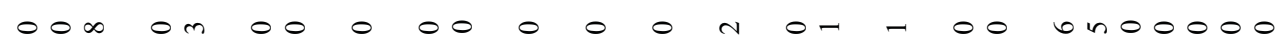

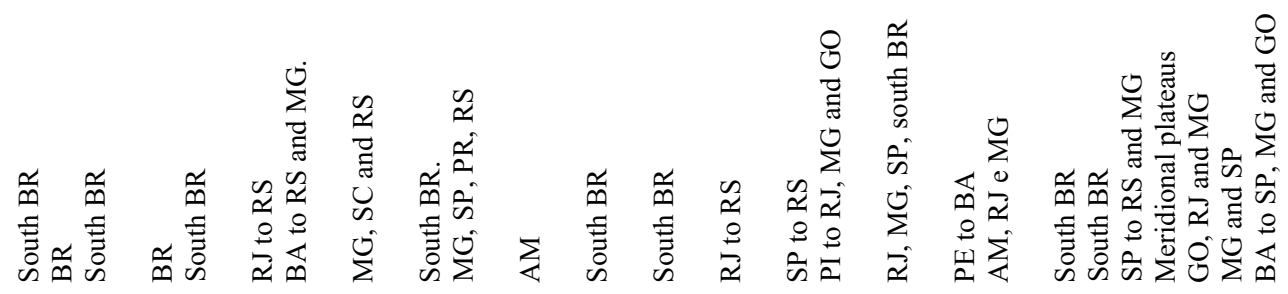

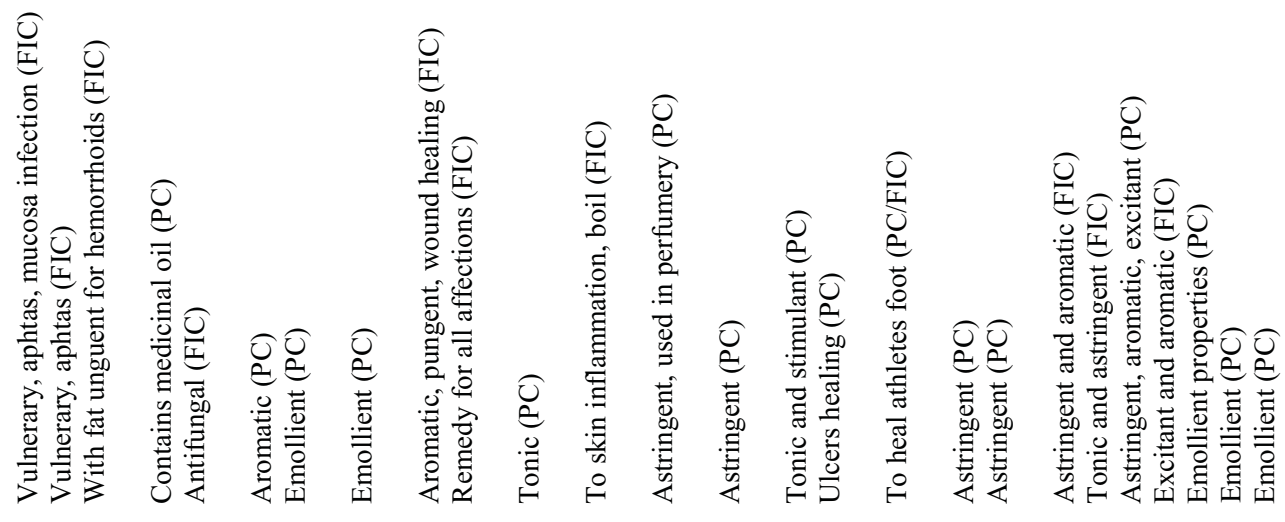

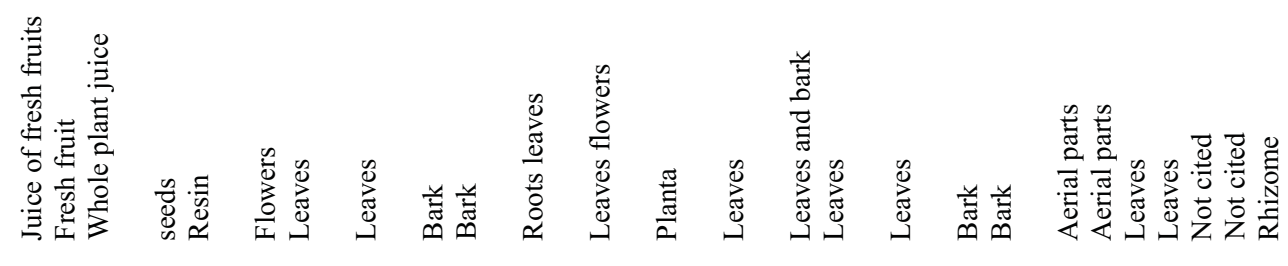

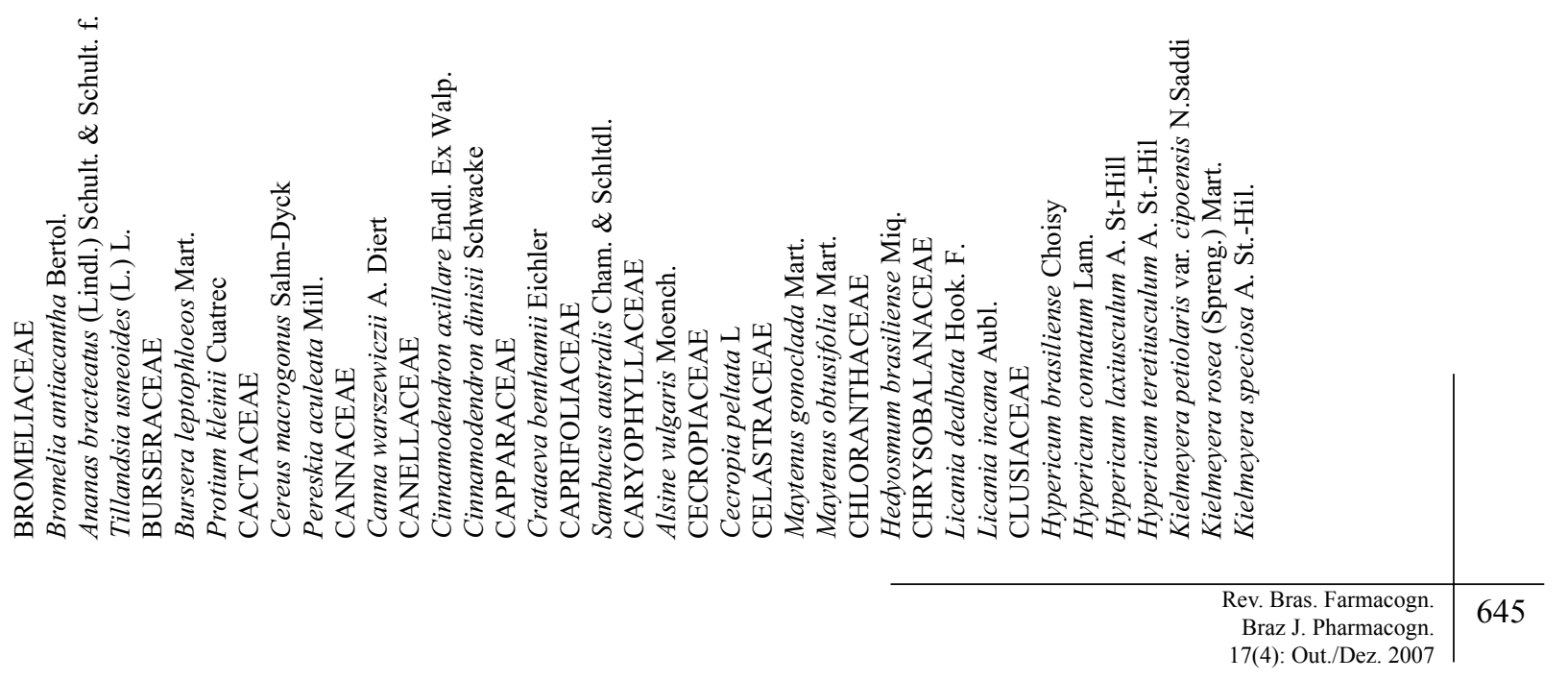


$0=$ onogn o ĩo-

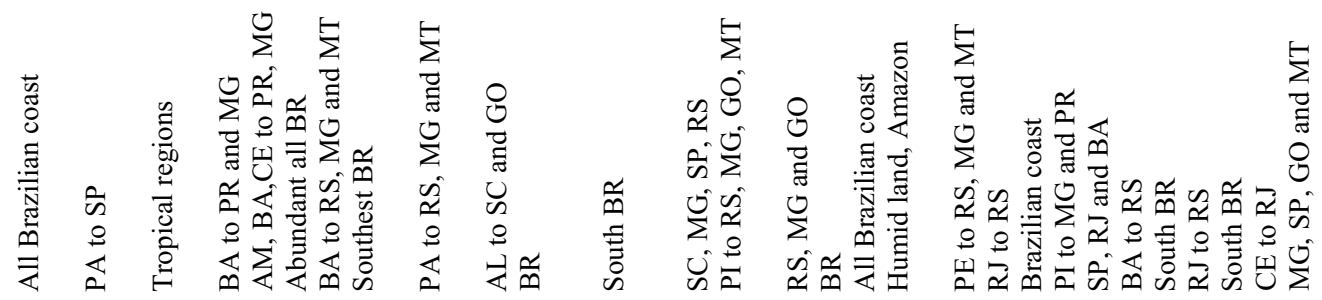

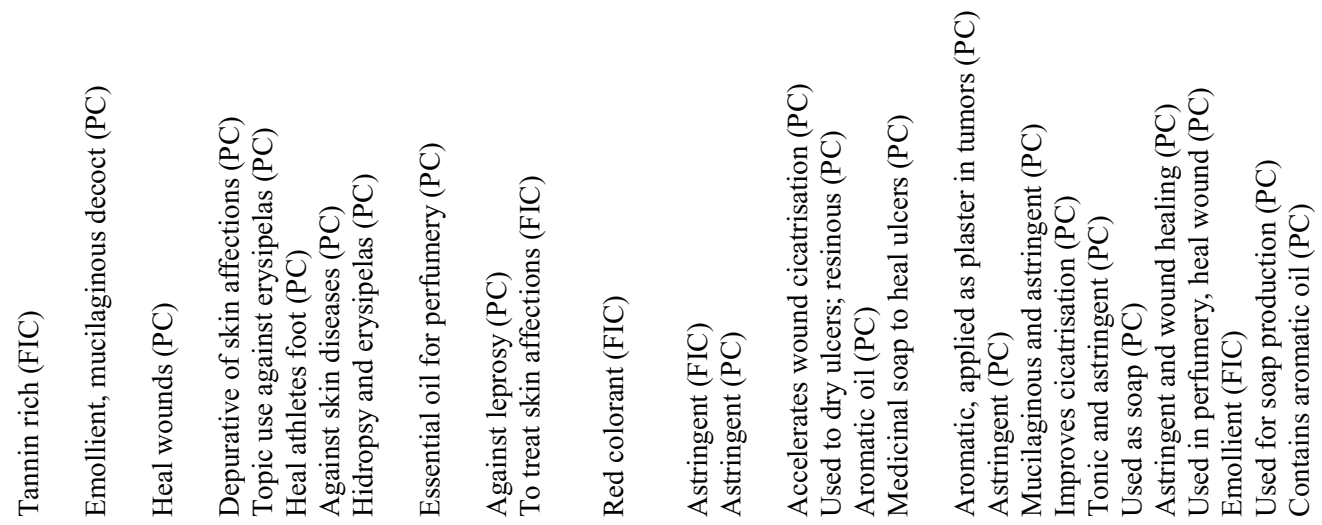

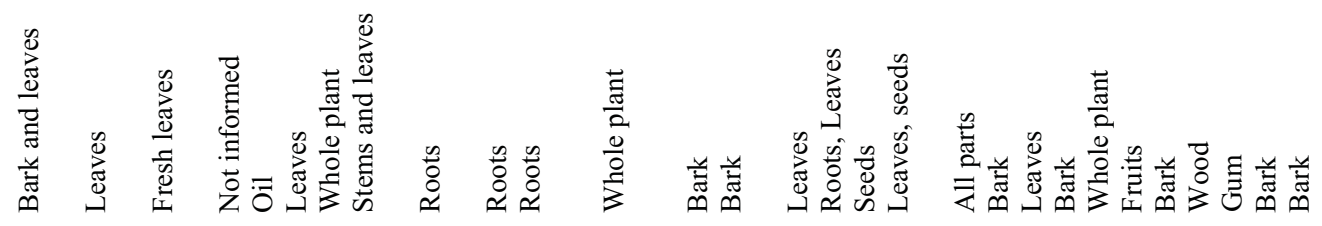

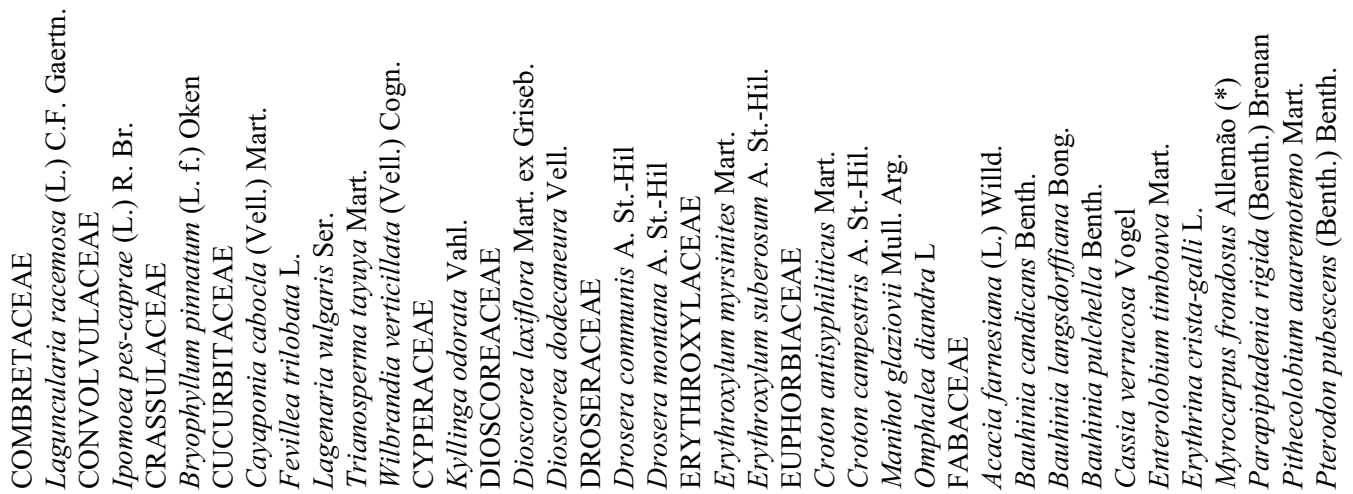


ofnoo o o o ommo oOnOO o o o m o- 000

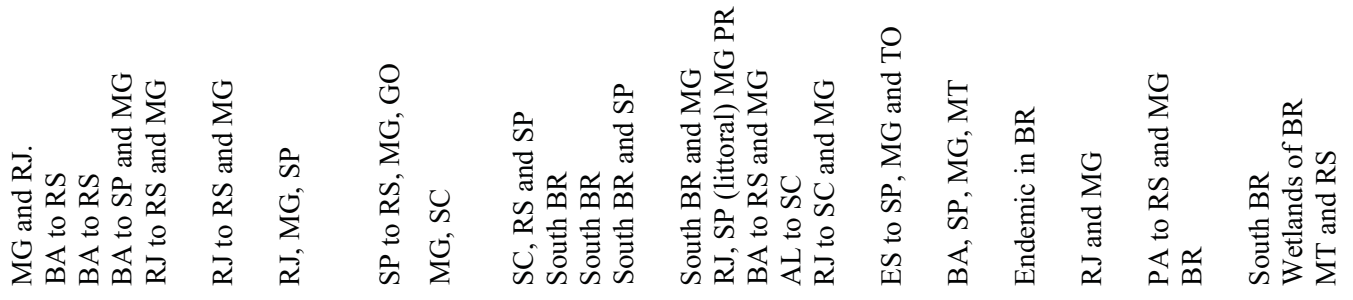

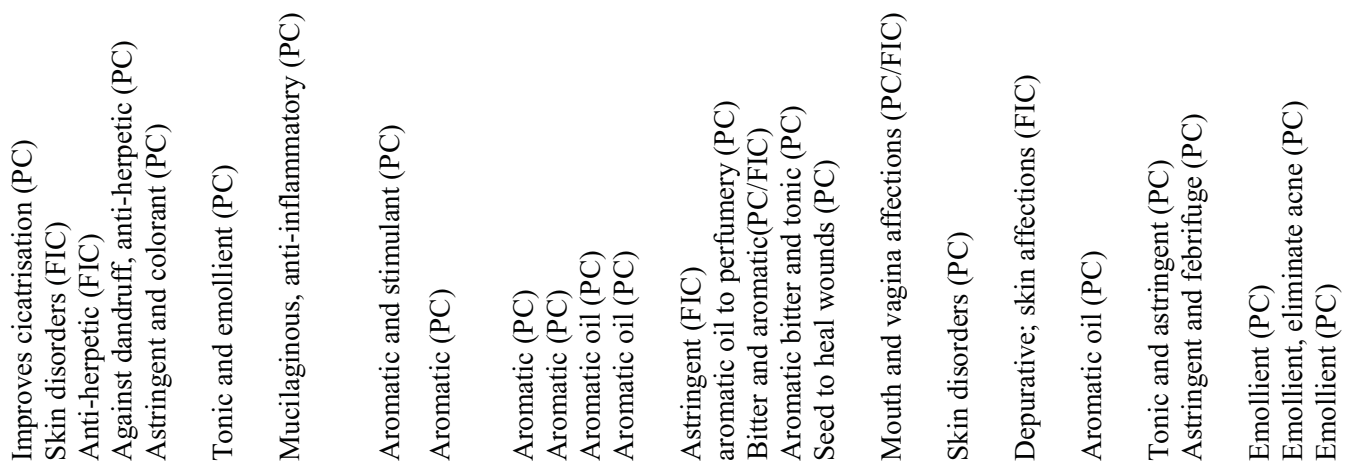

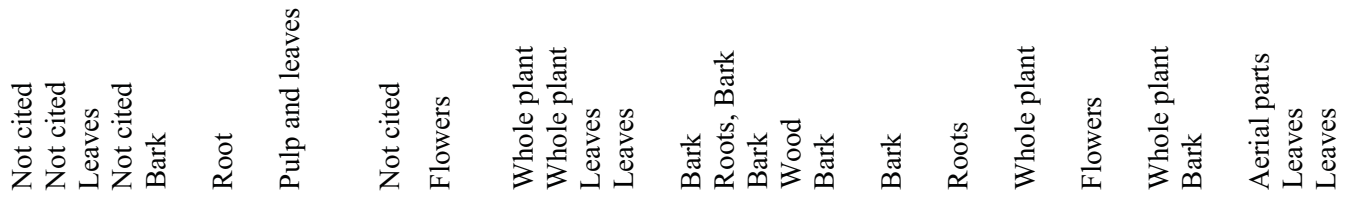

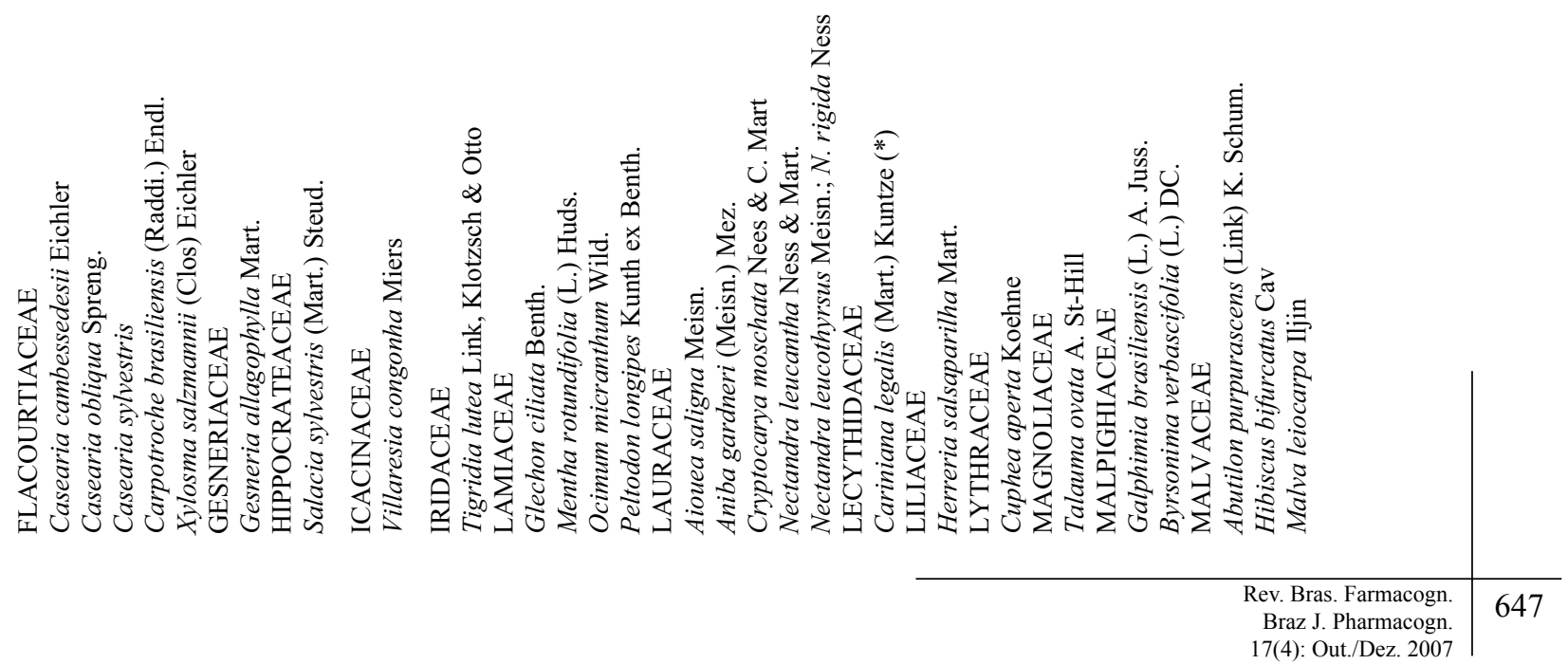


$00000-n n O b N$ nt in 000000000000000

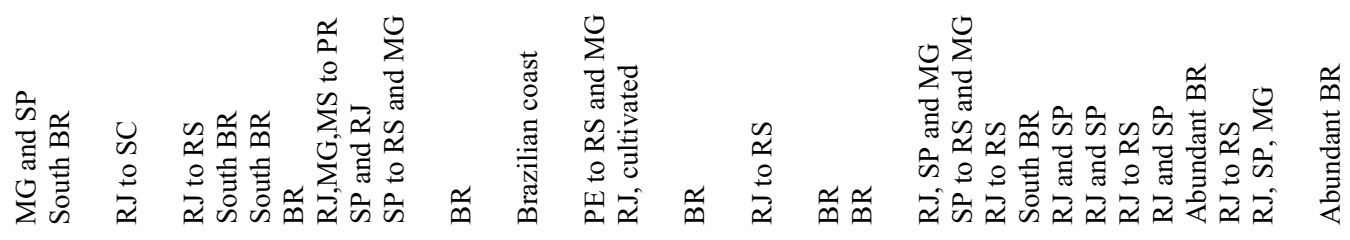

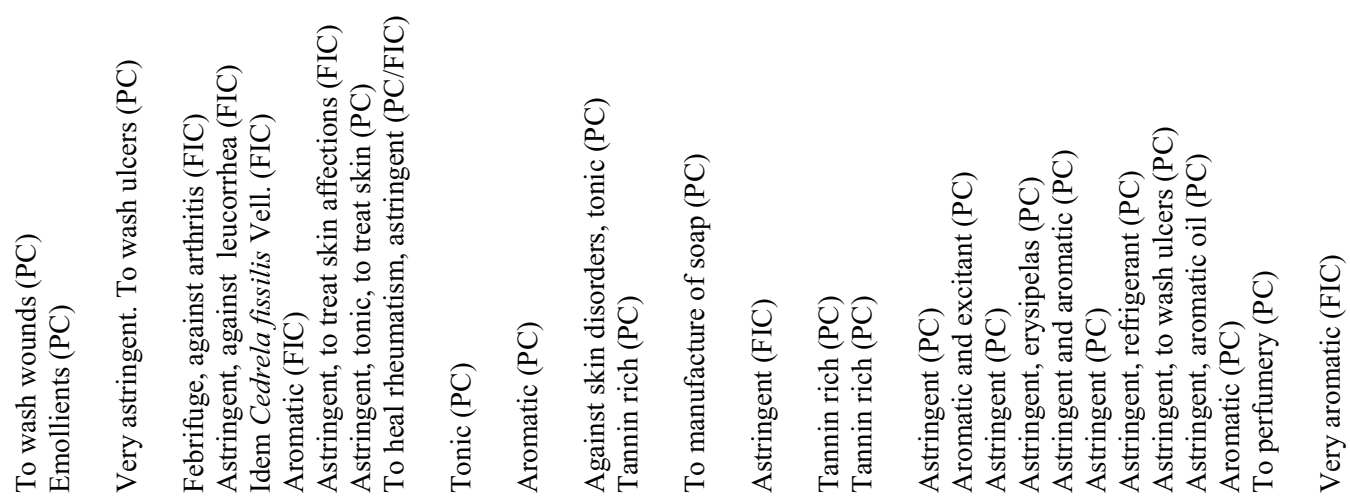

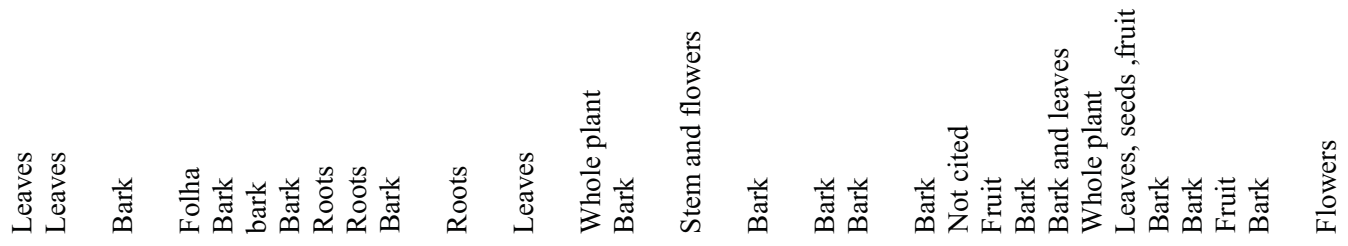

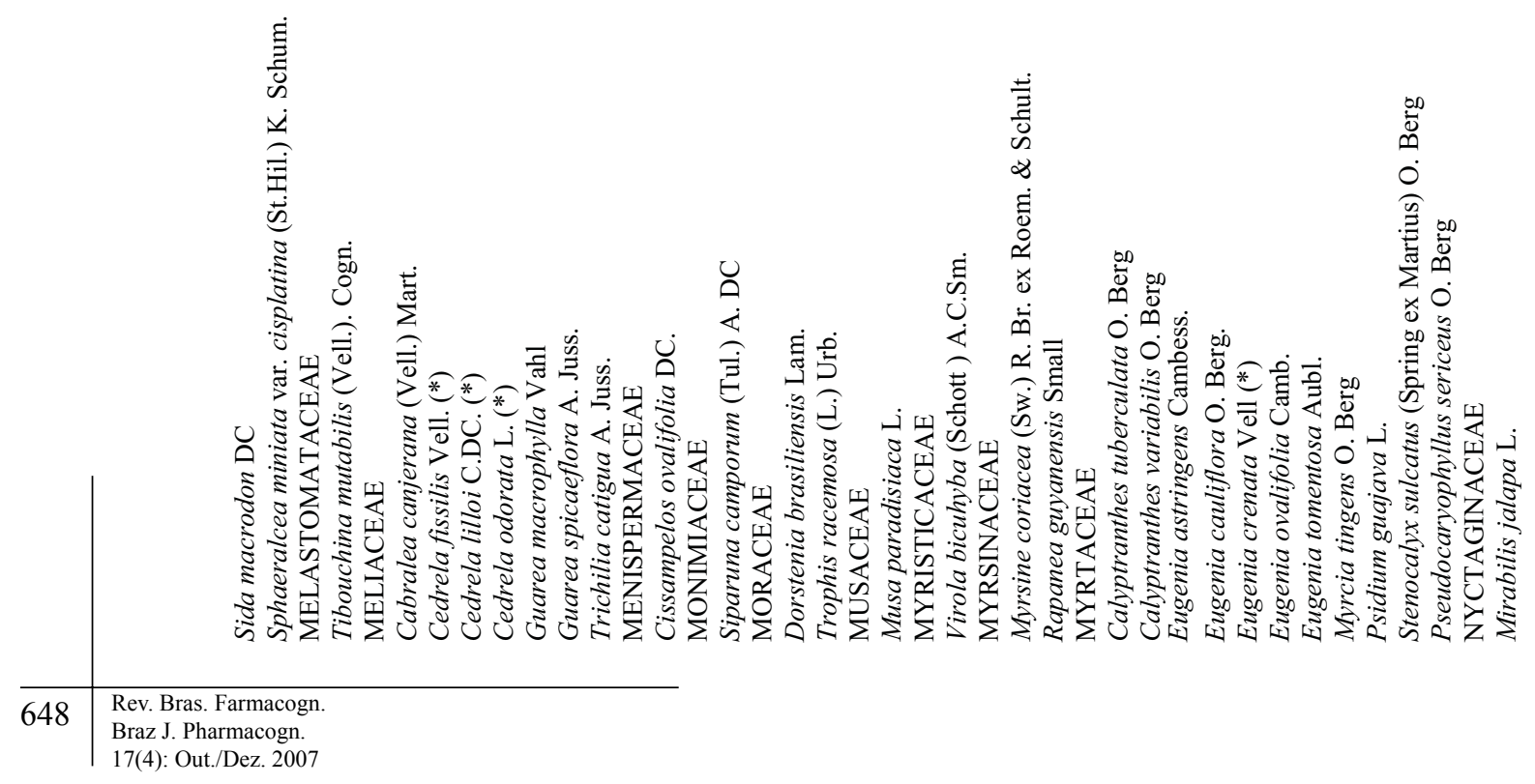


$0000000-0-1000-0000$ mo o lo 0

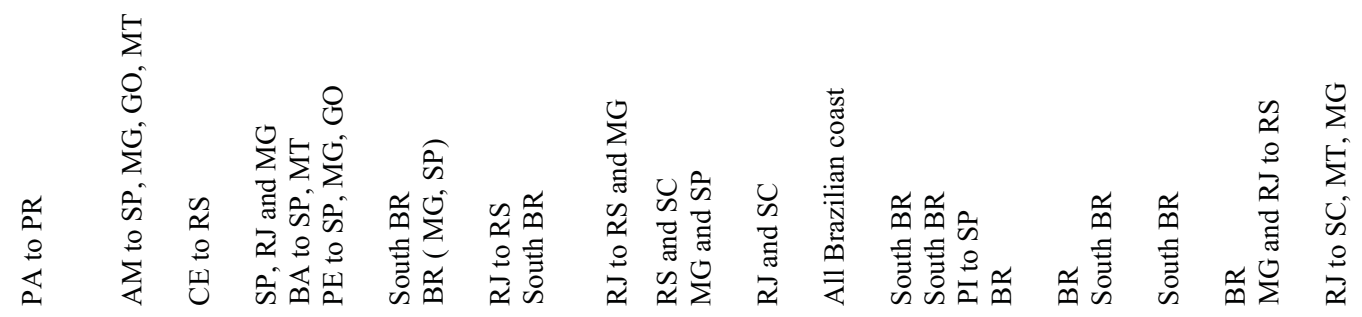

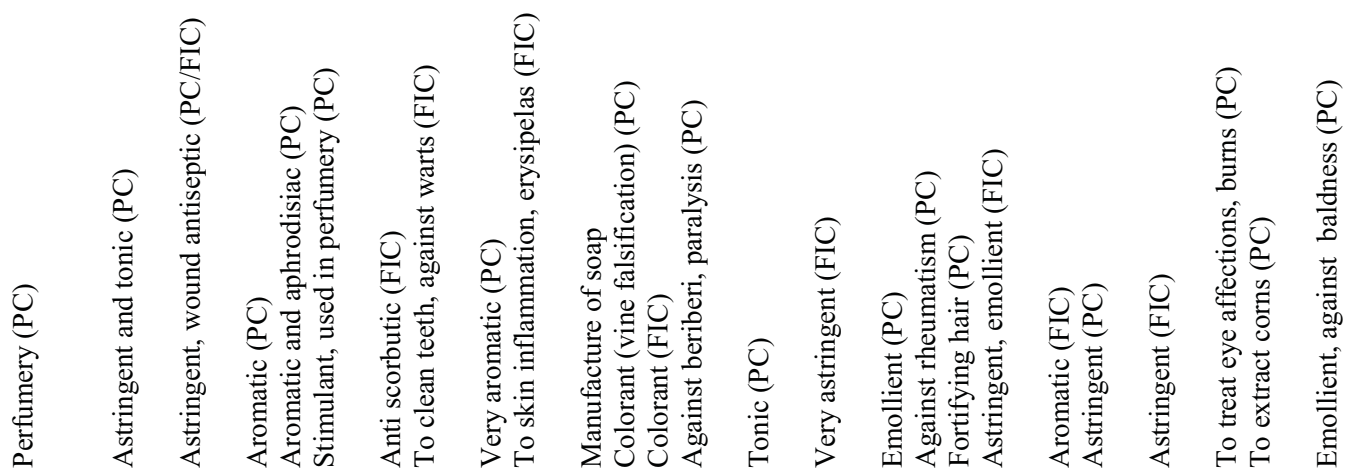

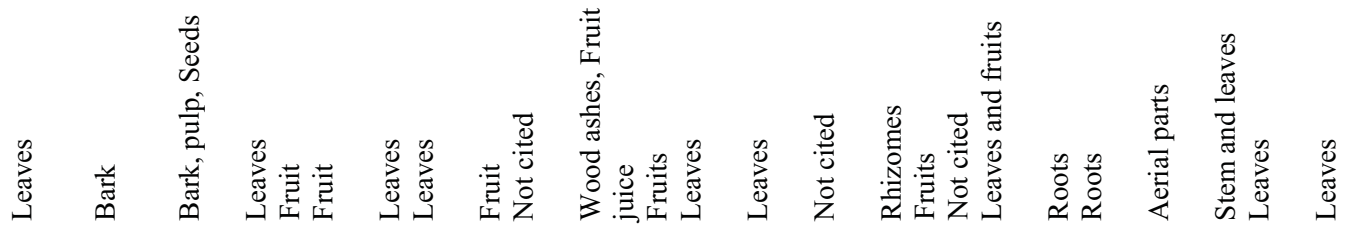

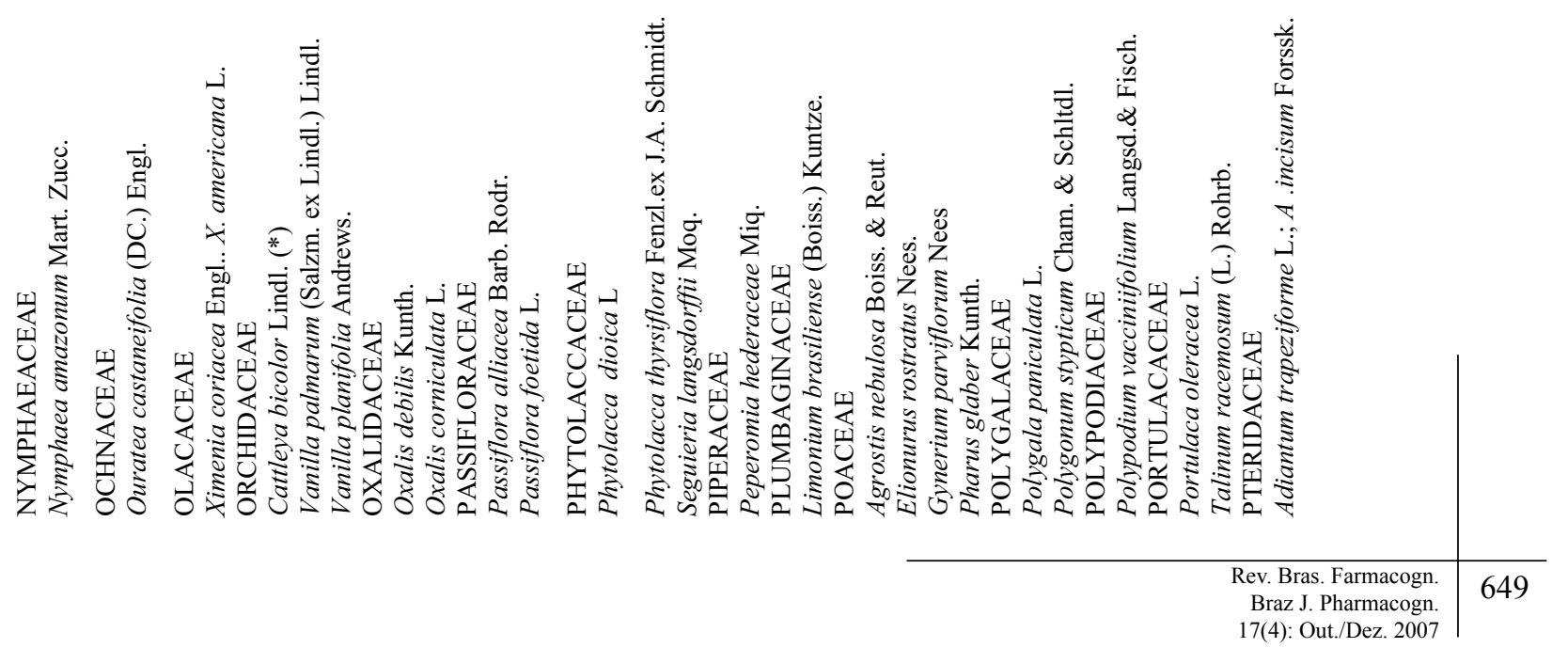




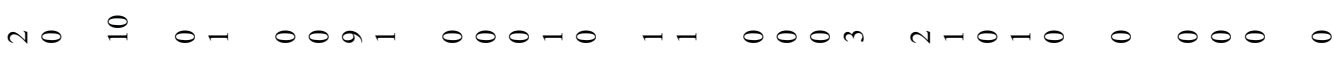

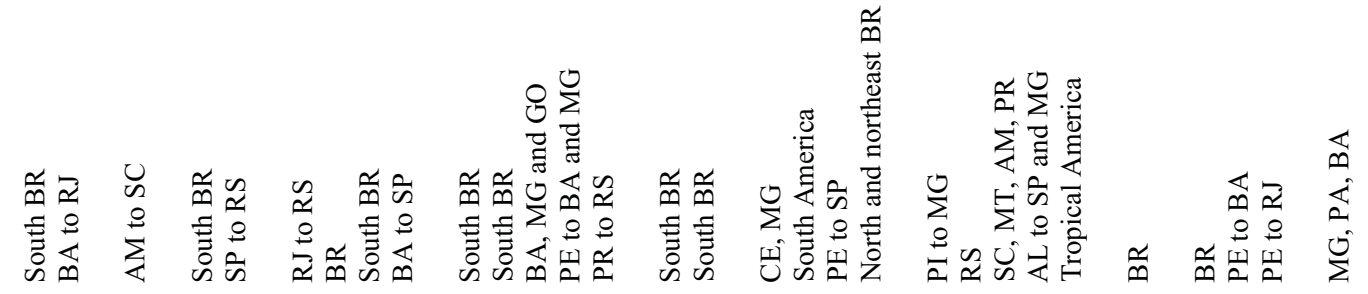

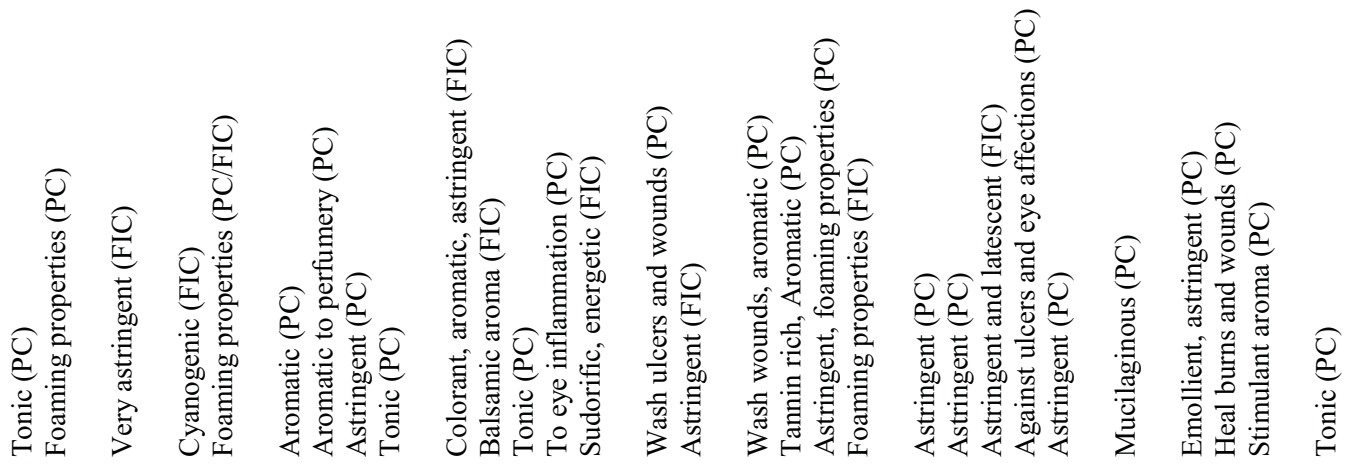

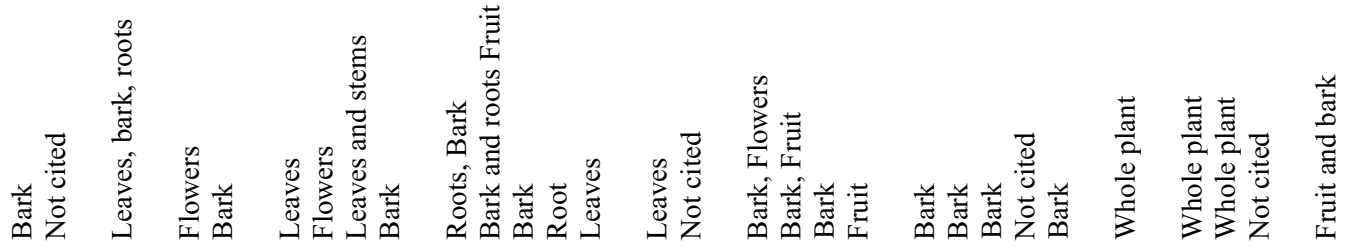

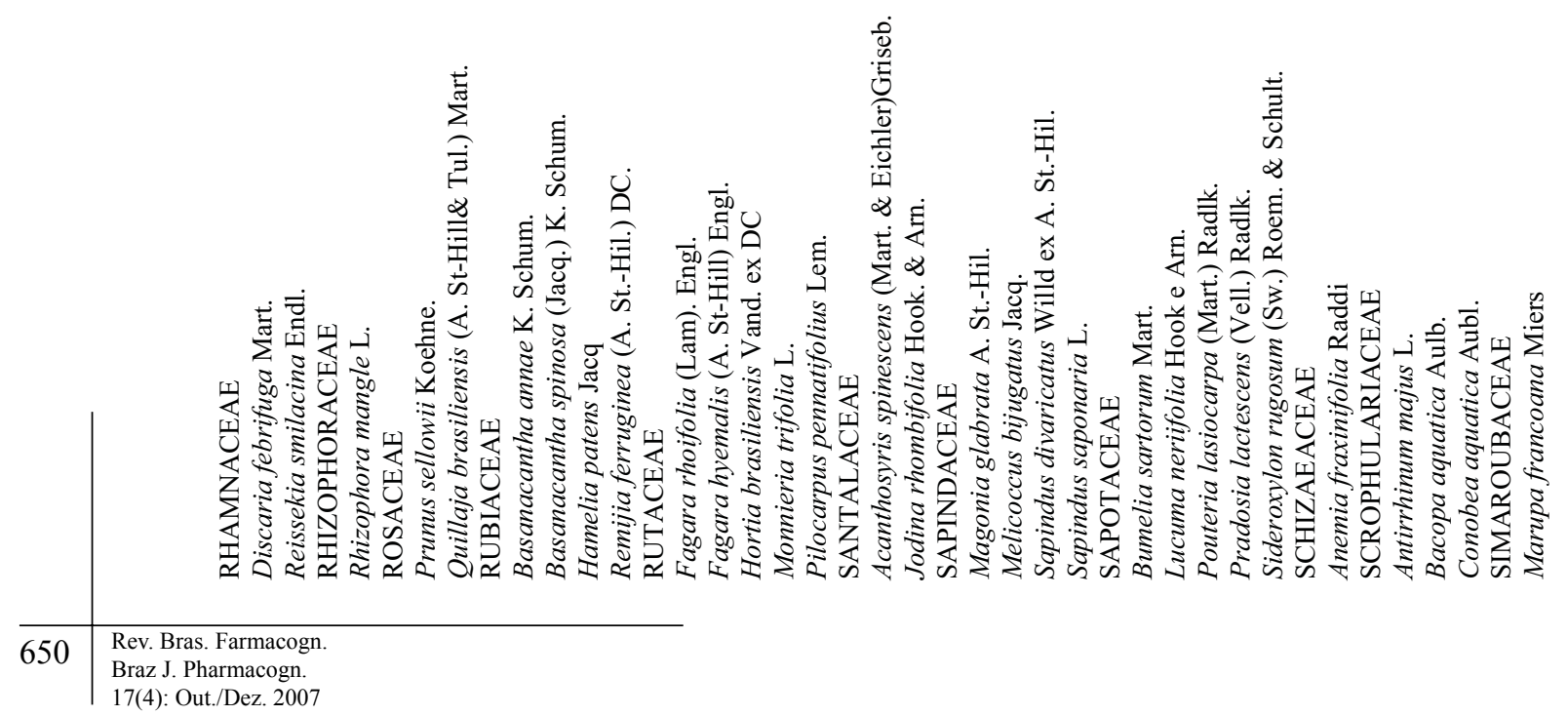




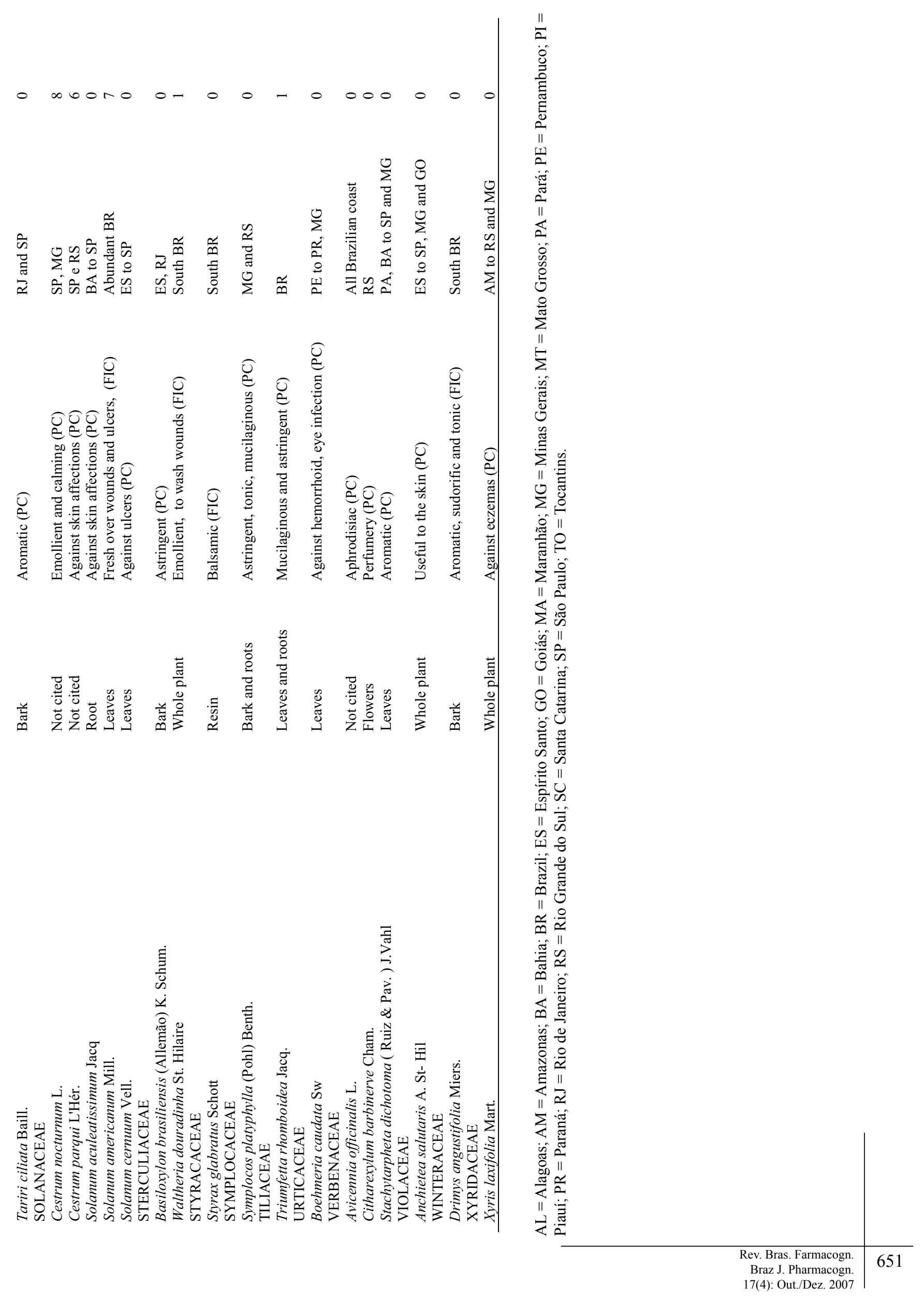


characteristics of interest for cosmeceutical purposes are: aromatic or essential oil $(\mathrm{n}=66)$, mucilages $(\mathrm{n}=$ $12)$, tannins $(n=10)$, foaming properties $(n=11)$ and resins $(n=02)$. In the forest, the most popular method of classifying plants is based on the bark color and shape, and this empirical classificatory system may be reflected in the number of citations of bark as the part of the plant used.

Proanthocyanidins or condensed tannins are a group of antioxidant active polyphenolic bioflavonoids that are synthesized by many plants. Proanthocyanidins and other tannins are known to facilitate wound healing (Khanna et al., 2001). The mode of action, however, remains unclear. Some authors speculate that antioxidant activity contributes favorably to the healing of wounds, because reactive oxygen species produced during the inflammatory process aggravate the disorders in the tissues (Lopes et al., 2005; Souza et al., 2007).

According to the Pubmed survey, most of the selected species $(65 \%)$ have not been previously investigated for potential cosmeceutical applications, neither has their chemical composition been investigated. This fact suggests that the data compiled in this work constitutes a valuable source of primary information for scientific investigation in cosmeceutical and related areas.

\section{ACKNOWLEDGMENTS}

The authors wish to thank Ana Claudia Araújo, for her help with the correct botanical identification of species and habitats of origin, and UNIVALI for its financial support.

\section{REFERENCES}

Agra MF, França PF, Barbosa-Filho JM 2007. Synopsis of the plants known as medicinal and poisonous in Northeast of Brazil. Rev Bras Farmacogn 17: 114-140.

Arcanjo FEM 2000. Intellectual property rights and biodiversity in Brazil: conservation, sustainable use and protection of the indigenous rights. Institute of Brazilian Business and Public Management Issues IBI. Minerva Program. www.gwu.edu/ ibi/minerva/ Fall2000/Eugenio.Arcanjo.pdf, accessed 11 Feb 2005.

Brandão M.GL, Cosenza GP, Moreira RA, Monte-Mor RLM 2006. Medicinal plants and other botanical products from the Brazilian Official Pharmacopoeia. Rev Bras Farmacogn 16: 408-420.

Buenz EJ, Schnepple DJ, Bauer BA, Elkin PL, Riddle JM, Motley TJ 2004. Techniques: Bioprospecting historical herbal texts by hunting for new leads in old tomes. Trends Pharmacol Sci 25: 494-498.

Buenz EJ, Johnson HE, Beekman EM, Motley TJ, Bauer BA 2005. Bioprospecting Rumphius's Ambonese Herbal: Volume I. J Ethnopharmacol 96: 57-70.
Di Stasi LC, Oliveira GP, Carvalhaes MA, Queiroz-Junior M, Tien OS, Kakinami SH, Reis MS 2002. Medicinal plants popularly used in the Brazilian Tropical Atlantic Forest. Fitoterapia 73: 69-91.

Galindo-Leal C, Camara IG 2003. The Atlantic Forest of South America: Biodiversity status, threats, and outlook. Washington, DC: Island Press, 488 p.

Khanna S, Roy S, Bagchi D, Bagchi M, Sen CK 2001. Upregulation of oxidant-induced VEGF expression in cultured keratinocytes by a grape seed proanthocyanidin extract. Free Radical Bio Med 31: $38-42$.

Leung AY, Foster S 2003. Encyclopedia of common natural ingredients used in food, drugs and cosmetics (2nd Edition): Wiley-Interscience, Hoboken, NJ, USA, $649 \mathrm{p}$.

Lopes GC, Sanches ACC, Nakamura CV, Dias Filho BP, Hernandes LM, de Mello JCP 2005. Influence of extracts of Stryphnodendron polyphyllum Mart. and Stryphnodendronobovatum Benth. on the cicatrisation of cutaneous wounds in rats. $J$ Ethnopharmacol 99: 265-272.

Marensi V 2004. Levantamento bibliográfico de espécies botânicas de aplicação tópica e as com potencial cosmético - com ênfase as pertencentes à Floresta Atlântica. Itajaí, 265p. Trabalho de Conclusão de Curso - Graduação em Farmácia, Universidade do Vale do Itajaí.

Mendonça-Filho RFW, Menezes FS 2003. Estudo da utilização de plantas medicinais pela população da Ilha GrandeRJ. Rev Bras Farmacogn 13(Supl): 55-58.

Missouri Botanical Garden 2003. Missouri Botanical Garden-w3 TROPICOS Nomenclatural Data Base.

Moraes MS 1986. Considerações sobre a pariparoba oficial Pothomorphe umbellata (L.) Miq. Rev Bras Farmacogn 1: 101-108.

Morais SM, Dantas JDP, Silva ARA, Magalhães EF 2005. Plantas medicinais usadas pelos índios Tapebas do Ceará. Rev Bras Farmacogn 15: 169-177.

Noonan WP, Noonan C 2004. Legal requirements for "functional food" claims. Toxicol Lett 150: 19-24.

Pieroni A, Quave CL, Villanelli ML, Mangino P, Sabbatini G, Santini L, Boccetti T, Profili M, Ciccioli T, Rampa LG 2004. Ethnopharmacognostic survey on the natural ingredients used in folk cosmetics, cosmeceuticals and remedies for healing skin diseases in the inland Marches, Central-Eastern Italy. J Ethnopharmacol 91: 331-344.

Ropke CD, Kaneko TM, Rodrigues RM, Silva VV, Barros S, Sawada TC, Kato MJ, Barros SB 2002. Evaluation of percutaneous absorption of 4-nerolidylcathecol from four topical formulations. Int J Pharmacol 249: 109-116.

Ropke CD, Meirelles RR, Silva VV, Sawada TCH, Barros SBM 2003. Pothomorphe umbellata extract prevents $\alpha$-tocopherol depletion after UV-irradiation. Photochem Photobiol 78: 436-439. 
Sant'Ana PJP 2002. A bioprospecção no Brasil - Contribuições para uma gestão ética. Brasília: Paralelo 15.

Souza GC, Haas AP, von Poser GL, Schapoval EE, Elisabetsky E 2004. Ethnopharmacological studies of antimicrobial remedies in the south of Brazil. J Ethnopharmacol 90: 135-143.

Souza TM, Moreira RRD, Pietro RCLR, Isaac VLB 2007. Avaliação da atividade anti-séptica de extrato seco de Stryphnodendron adstringens (Mart.) Coville e de preparação cosmética contendo este extrato. Rev Bras Farmacogn 17: 71-75.

The Plant Names Project 1999. The Jepson Herbarium. University of California, Berkeley, (http://ucjeps. berkeley.edu/about_ICPN.html). 